\title{
The Evolving Role of the Security Council in the Post-Cold War Period
}

\section{Joelle Hageboutros}

In 1945 at the end of World War II, the newly-founded United Nations aimed to replace the defunct League of Nations in ensuring world peace, security, and stability. The UN Security Council (SC) in particular was charged with the responsibility of "maintaining international peace and security" at a time when $90 \%$ of world conflicts were fought between states. (United Nations, 1948) (Doyle \& Sambanis, 2006, 11) However, faith in the council to uphold world peace quickly subsided as the Cold War rivalry between the U.S. and the USSR precluded effective collaboration.

The end of the Cold War in 1989 is often cited as a turning point in history and the beginning of a new world order. This is clearly evidenced in the rapidly increasing rate of productivity and a newfound spirit of cooperation in the SC. From 1991 to 1993 , the Council prolifically adopted 185 resolutions, as compared to 685 in the previous 46 years of the UN's existence. (Malone, 2004, 6) It also launched 15 new peacekeeping operations versus 17 in the preceding 46 years. (Malone, 2004, 6) Yet as the SC became reinvigorated, the nature of conflict had changed; $85 \%$ of all wars fought were now intrastate wars, many of which were ethnically and religiously driven civil wars. In 1992, the number of intrastate conflicts peaked at around 55 worldwide. (Doyle \& Sambanis, 2006, 11) (Pinker, 2011, 303) These concurrent issues have raised the following question: how has the SC reinterpreted its mission statement to better navigate the transition to the post-Cold War era regarding geopolitical organization and the change in the nature of conflict?

This paper will present three major ways in which the SC has evolved since the end of the Cold War. The first major trend to be analyzed is the emergence of the P5 (Russia, China, UK, France, US) as a more cohesive and cooperative unit and its implications on the changing nature of the Council's structure and larger mission. Next, the redefinition and evolution of the concept of sovereignty will be highlighted in terms of the novel involvement of the SC in domestic affairs of member states. Finally, the incorporation of a human rights discourse in the $\mathrm{SC}$ will be considered both as a result of the evolving norms in the international community and as a consequence of the Cold War ending.

\section{Security Council History: P5 Emergence}

In the Security Council, the Cold War ended not in 1989 but in 1986 when the powers first found common ground regarding the renewal of Secretary General Cuéllar's term. Soon after, the UK representative invited the $\mathrm{P} 5$ to informal negotiations outside of the UNHQ in hopes of discussing a solution to the Iran-Iraq War. (Malone, 2004, 4) Freed from formalities, the delegates found a frank discussion amongst themselves to be very productive, and were able to authorize an observer force and propose a ceasefire. USSR leader Gorbachev's 1998 address to the General Assembly (GA) introduced new faith in the council when he announced the Soviet Union would use the UN as the primary means of handling international conflicts. This implied that the USSR would retract from its overextended commitments throughout the world, thus marking the end of the Cold War global rivalry. This 
Soviet strategy was reciprocated with US cooperation in peace initiatives in Angola, Namibia, Cambodia, and Central America, which were sites of major Cold War proxy conflicts. (Wallensteen \& Johansson, 2004, 19) The Security Council was thus the stage for the end of the Cold War before the fall of the Berlin Wall and the dissolution of the Soviet Union.

One major trend following the increase in cooperation among the members includes the sharp decline of veto use among the P5. During the Cold War, the use of the veto was predictable. One camp would propose a draft resolution that was expected to be rejected by the opposing side. (Wallensteen \& Johansson, 2004, 20) The veto thus gained a propagandist nature as each side accumulated political points for its position on the resolution. After the Cold War, however, forcing fellow council members to vote for or against a specific resolution was viewed as "irresponsible." (Wallensteen \& Johansson, 2004, 20) While voting blocks still exist among the P5 along certain issues (e.g. Syria, Ukraine, Libya) member states have become more autonomous and cautious in wielding their vote. From 1946-1995, the veto was used a total of 244 times (approximately $29 \%$ by the U.S. and $50 \%$ by the USSR). (Global Policy Forum, 2015) The majority of vetoes that have been used since the Cold War (31 from 1996-2014) relate to issues concerning one member (e.g. Israel/Palestine for the US and Taiwan for China) who will predictably wield its veto alone.

The recent deadlocks among the P5 over Syria, Libya and Ukraine obscure the overall trend of a high rate of cooperation among the P5. Current Under-Secretary General David Malone argues that too often one forgets "on $90 \%$ of the Council's agenda which are even more murderous conflicts [than Syria, Libya, Ukraine] often in Africa, places like the Congo, the council has no trouble agreeing." (Malone, March 9) In 2014 alone, the SC passed 60 out of 63 resolutions unanimously. (United Nations Security Council, January 2015, 8) The three aforementioned cases are nevertheless important signifiers of new trends emerging in the Council where Russia and China have become more vocal opponents. ${ }^{1}$

Cooperation among the P5 members of the SC since the late 1980s has resulted in a redistribution of tasks and prestige once accorded to the General Assembly and the Secretariat, that now favor the Council. During the Cold War, the GA overshadowed the deadlocked SC and even involved itself in security affairs, a duty normally reserved for the Council. In 1950, it passed Resolution 337A: "Uniting for Peace" which allowed the GA to consider a resolution that was blocked by the $\mathrm{SC}$ due to a lack of unanimity among the P5, and thus act accordingly. ${ }^{2}$ (Tomuschat, 2008) The GA has since lost influence and attention as the SC has been able to effectively resume its duties.

The role of the Secretary-General has also been diminished since the Cold War. In the 1950s, SG Dag Hammarsköld played a large role in mediating global conflicts (e.g. sending the first UN peacekeeping force to resolve the Suez crisis and aiding in the Congo decolonization process) based on the use of Article 99 of the Charter: "the Secretary-General may bring to the attention of the Security Council any matter in which his opinion may threaten the maintenance of international peace and security." (United Nations, 1948) In the postCold War period, however, the agenda for the Council is no longer set by the Secretariat, but by the Council members themselves. The Secretariat has also been faced

\footnotetext{
${ }^{1}$ This will be discussed at length in a later section concerning evolving conceptions of sovereignty.

${ }^{2}$ While it was created as a means to prevent further Soviet vetoes regarding the Korean War, the resolution was first invoked during the Suez crisis where France and the UK had blocked any action regarding the crisis. The measure was last invoked in 1981 to authorize economic and diplomatic sanctions on South Africa for its illegal occupation of Namibia.
} 
with a strain on resources, allowing the Council to assume a more active role in the implementation of resolutions, a task usually reserved for the SG. (Wallensteen \& Johansson, 2004, 21)

There has also been a structural shift in how the Council performs its daily work. Since the Cold War, the P5 has dominated drafting sessions and decisions are made more often behind closed doors during informal consultations among the P5. This only increases the sentiment among the rest of the council (E10) and UN members that the SC is an "exclusive club" for the P5. The E10 argues that the human rights catastrophes in Yugoslavia and Rwanda relate in part to the fact that the $\mathrm{P} 5$ did not disclose exclusive information regarding the conflicts with other members. In response, "Arria formula" meetings have developed, where NGO and human rights investigators are invited to brief the council. NGO presence and lobbying of SC members have now become commonplace.

While greater cooperation among the $\mathrm{P} 5$ has resulted in more innovative forms of conflict resolution (creation of international tribunals in the former Yugoslavia, Rwanda, and Lebanon as well as the establishment of the ICC), the role of the SC has become more of a delegating body rather than an enforcing power with regards to peacekeeping. Although the amount of Chapter VII resolutions has multiplied following the Cold War, this has been paralleled by an increasing inability to effectively follow through with enforcement operations.(Weiss, 2004, 46) This is due to a lack of UN funding, an inadequate military force incapable of handling the nature of internal conflicts, and risk-averse member states. SC peacekeeping failures in Bosnia and Rwanda marked the end of unilateral UN military action. ${ }^{3}$ Instead, the Council began to delegate the enforcement operations to regional organizations (i.e. NATO, African Union, Arab League) and "coalitions of the willing" (i.e. Albania). Instead of being the active enforcer of world peace and security as was envisaged in the Charter, the SC has become a bureaucrat worker, rubber stamping its seal of approval on operations led by other groups. By engaging in "buck-passing," the SC attempts to profit from immunity while minimizing costs. ${ }^{4}$ Thus while the Council has benefited from an unprecedented rate of cooperation and effectiveness, the emergence of the P5 has simultaneously overshadowed the role of other UN bodies and diminished its own role as the sole leader and enforcer of peace and security in the world, as the complexity of the nature of conflict necessitate burden-sharing with other regional organizations.

\section{The Security Council's Changing Conceptions of State Sovereignty}

Globalization in the post-Cold War era has eroded traditional concepts of state sovereignty, as capital, people, ideas, and information flow largely unhindered across national borders. In response, the SC has redefined its understanding of state sovereignty and what constitutes "interna- tional threats to peace and security," as a means of addressing its continuous role in mediating conflicts despite their changing forms. The main difference in the Council's conception of state sovereignty pre- versus post-Cold War derives from a newly perceived link between domestic stability and

\footnotetext{
${ }^{3}$ SC-sanctioned "safe zones" were unable to prevent the Srebrenica massacre in Bosnia and an intentionally weakened force in Rwanda was not empowered to stop the genocide.

4 "Buck-passing" refers to a realist conception of strategies states employ in a multipolar world in order to contain a rising hegemon. John Mearshimer argues that when rising states do not share a border with great powers, the tendency to "buck-pass" increases, as the perceived threat is not as great.(Mearsheimer, 2010)
} 
international security. After the Cold War, policy makers and academics challenged the traditional and realist means of maintaining world order with superior military capability, deterrence, and respect for state sovereignty. (Barnett \& Weiss, 2011, 77) The growing amount of internal conflicts proved to have destabilizing regional and global effects as violence often did not respect state borders or international norms and values. Additionally, these "new wars" shifted the understanding of civilians in conflict zones as they were no longer casualties but deliberate targets of war. ${ }^{5}$ The predicaments of unprecedented numbers of refugee spillovers into neighboring countries (which doubled from 13 to 26 million from 1987 to 1994) and the recognition that failed states are prime breeding grounds for terrorists convinced SC members that domestic instability is relevant to their mission of ensuring international peace and security. (Luck, 2006, 90)

The two solutions proposed by the Council have been economic and democratic liberalization. After the Cold War, the Council viewed democracy favorably as it "no longer demarcated the fault line between East and West." (Fox, 2004, 72) It linked lack of democracy with causes of civil wars and praised democratic governments' abilities to engage in national reconciliation and ensure security and stable institutions. Most importantly, the Council lauded democratic countries' ability to "self-police," thus decreasing the likelihood of a return to conflict and reducing the burden on the resource-strained UN to intervene. (Fox, 2004, 69-70) In 1993, for the first time in UN history, the Council urged a member state - Somalia - to transition to democracy. It even endorsed military intervention for regime change in Haiti after a military coup deposed the democratically elected leader. (1994 Resolution 940)(Barnett \& Weiss, 2011, 78)

All this can be explained by a theoretical shift in the conception of sovereignty from "negative" to "positive" as defined by international relations professor Robert Jackson. Negative sovereignty is understood as Westphalian sovereignty where internal matters of states are protected from international interference. Positive sovereignty, on the other hand, is dependent on the existence and respect of democratic principles and rule of law in a state. It is a "substantive rather than a formal condition." (Jackson, 1990, 29) This means sovereignty is no longer an accepted protection against accusations of violations of human rights and thus validates UN intervention in domestic affairs. Today, a state is not only expected to have and respect a contract between the government and the people, but also a contract between the government and the international community. (Barnett \& Weiss, 2011, 77) While tensions continued to surface over the relationship between state sovereignty and the legitimate use of force (especially in 1988 and 1999 over Iraq and Kosovo), the overall trend in the post-Cold War decade slowly eroded traditional conceptions of state sovereignty. The Council's intervention in realms of traditional state sovereignty has since become normalized; more often than not, the Council has been criticized for its inaction with regards to state violations of human rights rather than for its breach of state sovereignty.

The implications of this changed conception of sovereignty can be seen in the evolution of UN peacekeeping. While there is no direct reference to peacekeeping in the UN Charter, it has often been informally referred to as "Chapter VI $\frac{1}{2}$ " as it combines elements of Chapter VI: "Pa-

\footnotetext{
"The emergence of these "new wars" can be understood by the impact the end of the Cold War had on the "technology of rebellion" available to rebel groups and the state.(Kalvyas \& Balcells, 2010) The proliferation of small arms and the increasing emphasis of identity and ethnicity in the conflicts also contribute to these "new conflicts". While elements of identity and ethnicity are not "new" causes of war, their renewed emphasis in an era of globalization and fluidity of identity as the main motivations for war, combined with the new tools of war allows us to label these conflicts as "new."
} 
cific Settlement of Disputes" and Chapter VII: "Action with respect to threats to the peace, breaches of the peace, and acts of aggression." (Luck, 2006, 37) Strategies for building and keeping the peace have evolved through three generations. (Doyle \& Sambanis, 2006, 11) The first generation is understood as a force dispatched to monitor the situation after a truce has been negotiated. A prime example is the creation of the first UN peacekeeping force in 1956 in Egypt over the Suez Crisis. This first generation of peacekeeping has a tendency to enforce the status quo ante, which is not suitable for internal conflicts where the status quo ante is not accepted by the parties and is usually the cause of the conflict. (Doyle \& Sambanis, 2006, 12)

After the Cold War, the second generation of peacekeeping accorded greater responsibility to the peacekeepers to enforce the peace including tasks for resettling refugees and overseeing the demobilization of military forces. It also added a "peace building" dimension regarding oversight of human rights, economic rehabilitation, and organization of elections. (Doyle \& Sambanis, 2006, 11-13) This demonstrates a nuanced understanding of the different components necessary to rebuild the peace. Examples of second generation peacekeeping include SC Resolution 637 in 1990 concerning El Salvador. ONUSAL (UN Observer Mission in El Salvador) was created and authorized by the SC with a humanitarian mandate to oversee the human rights situation and investigate potential violations. (Weschler, 2004, 56) Thus monitoring elections, human rights, and reconstruction demonstrate the Council's evolving view of the link between democracy and conflict prevention.

Under a radically liberal interpretation of Chapter VII and conception of sovereignty, the third generation of peace- keeping has allowed UN missions to operate without the consent of the country in which they are intervening. This was designed specifically for intrastate conflicts where warring parties are not always easy to identify as "stable negotiating partners." (Doyle \& Sambanis, 2006, 11) Third generation peacekeeping operations include a wide range of activities from protecting the delivery of humanitarian aid to physically intervening to enforce a peace agreement. (Doyle \& Sambanis, 2006, 16) The goal here is to force and enforce the peace. While third generation peacekeeping gives unprecedented power and seemingly limitless options to the SC in this regard, the Council is hesitant in even threatening the use of force and usually resorts to operations which require less military commitment (e.g. establishment of no-fly zones). While the Council has given itself the tools and the widely-accepted justification on the basis of human rights to be forceful and active in preserving the peace, logistic realities and growing vocal RussoChinese opposition prevent the Council's peacekeeping activities from reaching their full potential.

Nevertheless, the evolution of peacekeeping reflects a new vision of the UN that is adapting to meet the different exigencies of modern conflicts. The SC has thus reinterpreted its mandate to expand the definition of what constitutes "international peace and security" in the post-Cold War era after witnessing the unprecedented repercussions of internal wars and recognizing its own inability to meet these repercussions with a traditional understanding of sovereignty. Thus the shift in its definition of sovereignty can be seen both as a reaction to the changed nature of conflict and as a product of globalization which normalizes values that emphasize the importance of democracy and respect for human rights in relation to conflict prevention.

\section{Human Rights Discourse in the Security Council}

A third major change in the Security Council concerns the introduction of the dis- course of human rights and its increasing 
relevance in Council affairs. While human rights were recognized in the UN Charter (1945) and later enshrined in the Universal Declaration of Human Rights (1948), the extent to which individual states were legally obliged to protect human rights and comply with the charter was contested and overshadowed by a larger goal of international cooperation in the promotion of human rights. (MacFarlane \& Khong, 2006, 86) Yet the human dimension of this conflict was never mentioned in SC resolutions until the Six-Day War in 1967. (Weiss, 2004, 38) During the Cold War, great powers did not want to alienate ascending third world members by enforcing compliance with human rights as qualifications for membership. ${ }^{6}$ The US and USSR also did not want these concepts to intrude on their bid to divide the world into "spheres of influence." (MacFarlane \& Khong, 2006, 105)

The end of the Cold War, however, did not bring about an automatic transition to championing human rights in the Security Council. Rather, it was a gradual process of selectively and inconsistently invoking human rights language to justify resolutions. In January 1992, at the Council member summit to address "expanding horizons," humanitarian concerns were not seen as a primary responsibility of the Security Council, but were characterized as a vague responsibility for "the United Nations membership as a whole, working through the appropriate bodies". (Luck, 2006, 84) SG Boutros Boutros-Ghali (19921996) rarely addressed the issue of human rights, and when he did, he expressed the belief that it was an internal matter. (Weschler, 2004, 63) The failures of the SC in Bosnia and Rwanda as well as the NATO intervention in Kosovo without SC authorization called for a reconceptualization of UN humanitarian in- tervention and peacekeeping. Part of this new thinking evolved outside of the Council. SG Kofi Annan (1997-2006) incorporated human rights into his agenda and emphasized their importance and relevance to all UN matters. The concept of "human security" was also first mentioned in the "Human Development Report of 1994," which called for an expansion of the definition of international security that specifically factored in the human element. ${ }^{7}$ In a delayed fashion, the Security Council adopted the trend of human rights discourse that was already prevalent in other UN bodies. When Canada assumed the presidency of the Security Council in February 1999, it actively placed human rights at the forefront of the agenda of the Council. (MacFarlane \& Khong, 2006, 175) The following year, the SC passed Resolution 1296 which stated:

deliberate targeting of civilian populations or other protected persons and the committing of systematic, widespread and flagrant violations of international humanitarian and human rights law in situations of armed conflict may constitute a threat to international peace and security, and in this regard, [the $\mathrm{SC}$ ] reaffirms its readiness to consider such situations and, where necessary, to adopt appropriate steps. (MacFarlane \& Khong, 2006, 175-176)

While the Council had finally expanded its definition of what constituted international security to include the human element, the language of the resolution still remained cautious and hesitant.

Nevertheless, this resolution set a precedent for the concept of "Right to Protect" (R2P), developed in 2001 and adopted in 2005 by the GA. Coined by the ICISS (International Commission on

\footnotetext{
${ }^{6}$ These new members were also suspicious of acts that would reduce their newly attained sovereignty.

7 "the concept of security has for too long been interpreted narrowly: as security of territory from external aggression, or as protection of national interests in foreign policy or as global security from the threat of a nuclear holocaust. It has been related more to nation states than to people."(United Nations Development Programme, 1994)
} 
Intervention and State Sovereignty), R2P attempts to reconcile national sovereignty and ethical humanity. (Doyle, 2015, xi) This changed the nature of the debate from the right of powers to invade, to the rights of "affected populations to assistance and protection" and the obligation of the international community to heed those calls. (Weiss, 2004, 41) In 2005, the GA limited legitimate intervention to: genocide, war crimes, crimes against humanity, and ethnic cleansing. (Doyle, 2015, 112)

Both China and Russia - staunch supporters of traditional "negative" sovereignty - expressed their cautious approval of this evolution of sovereignty. For liberal theorists like John Ikenberry, the fact that China especially no longer maintains the rigid conception of sovereignty to which it once held firm, demonstrates the effective integration of China into the international system and an internalization of accepted norms. ${ }^{8}$ China agreed to $\mathrm{R} 2 \mathrm{P}$ only when it was assured that it could only be applied with the approval of the Council, which would serve as a check to irresponsible use of the doctrine. (Ferdinand, n.d., 4) This can be seen as a step towards the reconciliation of China's role in global governance and its traditional doctrine on state sovereignty. R2P has symbolized the evolution of what are deemed appropriate interventions. The normalization of R2P language even has the potential to be considered an official part of international law rather than a non-binding GA proposal.

Yet the normalization of R2P potentially borders on abuse when used as a justification for intervention beyond humanitarian concerns. The use of R2P in 2011 regarding Libya and the debacle that ensued following allegations of NATO overstepping its SC mandate has produced unan- ticipated backlash from the P5 members who abstained from the resolution (China and Russia). R2P was invoked in response to the crackdown of former Libyan leader Gaddafi on "freedom fighters" and out of fear that he was preparing for a "bloodbath". (Kuperman, 2013, 108) Unlike previous cases in which R2P was invoked (e.g. SC Resolution 1674 on Darfur in 2006), it was the threat of mass violence rather than the violence itself, which justified the use of the doctrine. After the mandate expired and chaos in Libya ensued, NATO was accused of "mission creep" by pursuing regime change rather than protection of the people. ${ }^{9}$ (Kuperman, 2013, 113-115) Ikenberry's firm belief in the strength of institutions does not account for this possibility of the delegitimization of institutions (in the eyes of weaker or rising states in the system such as Russia and China) that could occur when the SC undertakes or approves such actions, thus facilitating the collapse of the delicate balance of "strategic restraint." Traces of this breakdown in cohesion can be seen as Russia and China consequently became more resolute and vocal when expressing their views in the SC. When it came to subsequent resolutions concerning the Syrian regime's crackdown on protesters later in the year, Russia and China no longer expressed their hesitance by abstaining, but were more explicit in their opposition by vetoing four subsequent resolutions that aimed to condemn the Syrian regime. This shows not only a return to their previous convictions in upholding "negative" sovereignty, but it also expresses a more self-confident approach in opposing Western discourse due to recent increases in both countries' economic and political significance. This NATO intervention could potentially have future im-

${ }^{8}$ This supports Ikenberry's belief in institutions and the power of "strategic restraint" whereby great powers are bound by rules and norms, and weaker and rising states like China are incentivized to abide by the world order by acquiring economic and political benefits and prestige. (Ikenberry, 2008)

${ }^{9}$ It could be argued that NATO's actions did not serve to protect civilians, but promote regime change. Kuperman claims NATO attacked many government forces in areas that did not represent a threat to Libyan civilians either because they supported the regime or were retreating and thus not attacking civilians. 
plications for the UN's repeated "outsourcing" of SC enforcement, thus raising the question of where ultimate responsibility lies when plans go awry.

\section{Conclusion: Prospects for Security Council Reform}

The Security Council has significantly evolved following the Cold War in adapting a humanitarian discourse, negotiating a new definition of sovereignty, and changing its approach to peacekeeping and conflict resolution missions to suit the "new" nature of conflict. The emergence of the P5 has also concentrated power and authority from different UN institutions into this select group of Council members. P5 members are increasingly perceived as an archaic group unrepresentative of today's great powers and thus unsuited as the sole leaders of the Council. Proposals for Council reform vary from G4 to Models A/B to the Italian model and have only increased in recent decades. ${ }^{10}$ While the proposed models take a step towards representational equity, their reliance on Euro-centric regional groupings or disproportionate continental groups highlight the difficulties of fairly representing the current global order.

A successful reform model must take into account the changing role of the SC. Consequently, those nations who contribute the most to the ever-increasing SCsanctioned peacekeeping missions (which are mostly developing nations), should have a greater say in the Council regarding the nature of their commitments. The reform model should also consider not only geographical representation, but also economic representation. Those who hold more economic weight, as well as those who contribute the most in terms of financial resources to the UN should have greater access to the Council. Lastly, SC reform cannot be effectively addressed without resolving the question of veto power. Increasing non-permanent or permanent representation does not change the fact of the P5 veto, which many view as illegitimate. While increased veto power might create more inefficiency in the Council in terms of preventing discussion on topics that are sensitive to the new veto-wielding states' national interests, abolishing it altogether would create its own problems. Even if this scenario is hard to imagine as the veto is fiercely protected by the $\mathrm{P} 5$, the removal of veto power could reduce the incentive for the major powers to stay in the organization. Ultimately, reform needs to be flexible and amendable for further future shifts in global political and economic orders.

Perhaps lessons from the gradual postCold War transition of the SC can shed light on the nature of the transition towards future reform of the Council. If so, reform will likely also follow a painfully slow process in relation to the evolving world, but the Council will eventually find a means to reconcile tradition and modernity. If it fails to do so, the Council risks losing all legitimacy as regional organizations become more empowered to act on issues of international security and bypass the UN, thus creating a similar pre-WWII skeletal system of authority in matters concerning international peace and security.

${ }^{10}$ The 2005 G4 (India, Germany, Brazil, Japan) each request permanent seats on the Council. Models A and B were both proposed by former SG in 2005. Model A advances the suggestion of adding six permanent seats (without veto power) distributed among Africa (2) Asia and the Pacific (2) Europe (1) and Americas (1) and three additional non-permanent seats. Model B propose a new group of eight 4-year renewable term seats (2 each for Africa, Asia and the Pacific, Europe, and the Americas) and one non-permanent seat. All proposals have only ever gained at most vocal support by P5 members, but have never been explicitly approved.(Hoffman \& Ariyoruk, May 2005) 


\section{References}

Barnett, Michael N., \& Weiss, Thomas G. 2011. Humanitarianism Contested: Where Angels Fear to Tread. Abingdon: Routledge.

Doyle, Michael. 2015. The Question of Intervention: John Stuart Mill and the Responsibility to Protect. New Haven: Yale University Press.

Doyle, Michael W., \& Sambanis, Nicholas. 2006. Making War and Building Peace: United Nations Peace Operations. Princeton: Princeton University Press.

Ferdinand, Peter. The Positions of Russia and China at the UN Security Council in the Light of Recent Crises. European Parliament Directorate-General for External Policies.

Fox, Gregory H. 2004. From the Cold War to the 21st Century. Lynne Rienner. Chap. Democratization, pages $69-84$.

Global Policy Forum. 2015. Changing Patterns in the Use of the Veto in The Security Council.

Hoffman, Walter, \& Ariyoruk, Ayca. May 2005. Special Paper No. 4: Security Council Reform Models: Models A and B, Italian (Regional) Proposal, Blue and Green Models and a New Model C. Tech. rept. Center for U.N. Reform Education.

Ikenberry, John G. 2008. The Rise of China and the Future of the West: Can the Liberal System Survive? Foreign Affairs, 28(1), 23-29.

Jackson, Robert H. 1990. Quasi-states: Sovereignty, International Relations, and the Third World. Cambridge University Press.

Kalvyas, Stathis N., \& Balcells, Laia. 2010. International System and Technologies of Rebellion: How the End of the Cold War Shaped Internal Conflict. American Political Science Review, 104(3), 415-29.

Kuperman, Alan J. 2013. A Model Humanitarian Intervention? Reassessing NATO's Libya Campaign. International Security, 38(1), 105-36.

Luck, Edward C. 2006. UN Security Council: Practice and Promise. Abingdon: Routledge.

MacFarlane, Neil S., \& Khong, Yuen Foong. 2006. Human Security and the UN: A Critical History. Bloomington: Indiana University Press.

Malone, David. 2004. The UN Security Council: From the Cold War to the 21st Century. Boulder: Lynne Rienner. Chap. Introduction, pages 1-15.

Malone, David. March 9, 2015. The UN Security Council in an Era of Great Power Rivalry. NYU Abhu Dabi Institute.

Mearsheimer, John J. 2010. The Tragedy of Great Power Politics. New York: Norton.

Pinker, Steven. 2011. The Better Angels of Our Nature: Why Violence Has Declined. New York: Viking.

Tomuschat, Christian. 2008. Uniting For Peace. United Nations Audiovisual Library of International Law. 
United Nations. 1948. United Nations Charter.

United Nations Development Programme. 1994. Human Development Report 1994. New York: Oxford University Press.

United Nations Security Council. January 2015. Highlights of Security Council Practice 2014. United Nations, 1-20.

Wallensteen, Peter, \& Johansson, Patrik. 2004. The UN Security Council: From the Cold War to the 21st Century. Boulder: Lynne Rienner. Chap. Security Council Decisions in Perspective, pages 17-33.

Weiss, Thomas G. 2004. The UN Security Council: From the Cold War to the 21st Century. Boulder: Lynne Rienner. Chap. The Humanitarian Impulse, pages 37-54.

Weschler, Joanna. 2004. The UN Security Council: From the Cold War to the 21st Century. Boulder: Lynne Rienner. Chap. The Humanitarian Impulse, pages 55-68. 